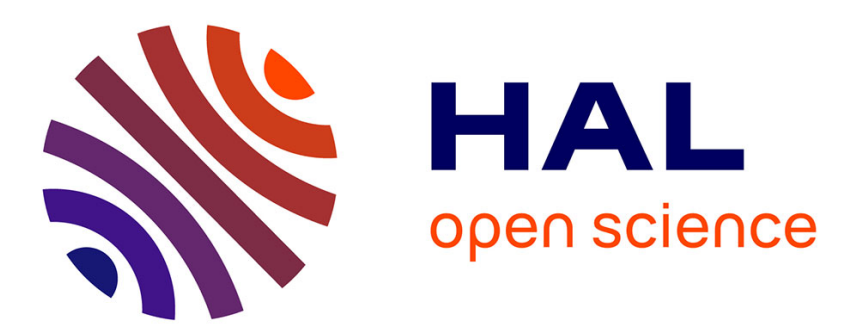

\title{
Well-designed mountain houses feature the only dated Pinus sylvestris type timbers in the southern French
} Alps

\author{
Lisa Shindo, E. Giraud
}

\section{To cite this version:}

Lisa Shindo, E. Giraud. Well-designed mountain houses feature the only dated Pinus sylvestris type timbers in the southern French Alps. Dendrochronologia, 2021, 67, pp.10.1016/j.dendro.2021.125833. 10.1016/j.dendro.2021.125833 . hal-03203174

\section{HAL Id: hal-03203174 \\ https://hal.science/hal-03203174}

Submitted on 20 Apr 2021

HAL is a multi-disciplinary open access archive for the deposit and dissemination of scientific research documents, whether they are published or not. The documents may come from teaching and research institutions in France or abroad, or from public or private research centers.
L'archive ouverte pluridisciplinaire HAL, est destinée au dépôt et à la diffusion de documents scientifiques de niveau recherche, publiés ou non, émanant des établissements d'enseignement et de recherche français ou étrangers, des laboratoires publics ou privés. 


\title{
Well-designed mountain houses feature the only dated Pinus sylvestris type timbers in the southern French Alps
}

\author{
Dendrochronologia, 2021, Volume 67, https://doi.org/10.1016/j.dendro.2021.125833
}

L. Shindo, Cluster of Excellence ROOTS, Kiel University, Leibnizstr. 3, 24118 Kiel, Germany

E. Giraud, L'Atelier d'Histoire, 05330 Saint-Chaffrey, France

Key words: Dendroarchaeology, Alps, farms, Larix decidua, Pinus sylvestris

\begin{abstract}
In the Southern French Alps, the Cervières Valley (near Briançon city) has traditional houses in which wood plays an important role, both in the buildings' structures and in the activities of the humans who lived there. The six studied farms bear witness to an architecture perfectly adapted to the mountain environment and to the daily and seasonal activities of the inhabitants. Dendrochronology has revealed four major phases of logging from the 16th to the 19th century. The 90 sampled timbers are from larch and Scots pine type, and are of similar age and calibre. The choice of species for building was probably made on the basis of their proximity to the building site. However, until now we have not yet identified any Scots pine t. from before the 18th century in the buildings. Does this represent a sampling bias or forest reality? Future historical and pedo-anthracological studies should provide answers. Although archaeological Scots pine is a recalcitrant species in dendroarchaeology in the Southern Alps, probably due to the presence of many missing rings, in this study a Scots pine t. average data have been dated using a larch reference chronology for the first time. This dating is supported by archaeological observations.
\end{abstract}

\section{Introduction}

\subsection{Geographical presentation}

In the Southern French Alps, on the Italian border and $8 \mathrm{~km}$ east of the town of Briançon, the Cervières Valley is located at the foot of the Izoard pass, which marks the border with the French Queyras region. The territory of the commune is bounded by several mountain ranges which culminate in the east at $3293 \mathrm{~m}$ above sea level. The Cerveyrette torrent crosses the Cervières Valley from east to west and merges with the Durance River at Briançon (Fig.1).

Upstream from the main hamlet, Chef-Lieu, the sunny southern slopes of the mountains have been converted by humans into fields and pastures. Hamlets for seasonal housing have been established there. Nowadays, old terraces are visible, but they are mostly abandoned and larch trees (Larix decidua Mill.) are gradually recolonising the area. On the heights, the few mountain pine (Pinus uncinata) trees that grow have a tortuous appearance. Downstream from the main hamlet, relief is steeper and there is a higher variety of species with forests of Scots pine (Pinus sylvestris L.), mountain pine (Pinus uncinata Ramond) and larch.

As long as the trees are standing, it is easy to determine their species. However, once they have been cut down and without their bark and leaves, identification is sometimes more complicated. This is the case with Scots pine. Indeed, Scots pine, mountain pine and black pine (Pinus nigra) cannot be distinguished on the basis of their anatomic characteristics (Schweingruber, 1990; Alvarez et al., 2009). However, black pine does not grow in this area and can be excluded, but there are still Scots pine and mountain pine. Therefore in this paper, concerning the beams identified in buildings, we have chosen to talk about "Scots pine type" (or "Scots pine t.") 


\subsection{Historical presentation}

From 1343 to 1789 , Cervières was part of an original institution: the "Escartons briançonnais" (from the Latin term "exquartonare", which refers to the tax distribution). In exchange for an annual tax paid to the prince of the region, the inhabitants had important liberties: they were free citizens, who could assemble as a community in order to make decisions, for example, on the passage of military troops or health surveillance during plague epidemics. The inhabitants of the Escartons were organised by village and by valley, led by consuls elected by the heads of families. Many textual documents have been produced and are preserved from 1508 onwards, which are a very rich source of information.

\subsection{A mobile lifestyle linked to the seasons}

The valley offers a vast agricultural terroir, from 1400 to $2500 \mathrm{~m}$ a.s.l. Until the inter-war period, the majority of the population lived from agriculture and farming. Even the few craftsmen had cattle and farmland for their subsistence. All Cervières hou ses are therefore farms.

The location of villages is determined by various imperatives: either on the slope to benefit longer from the sunshine or at the bottom of the valley at the main hamlet, Chef-Lieu, in order to use the hydraulic energy of the torrent for the two mills of the village.

The terracing of the agricultural land has led the inhabitants to adopt a way of life based on "changes" of habitat by going from one hamlet to another, according to the seasons. Michel Brunet, born in 1924, gives the dates of these successive moves of men and their livestock, during the $20^{\text {th }}$ century. From Christmas to April, the families occupy their houses in Chef-Lieu. From April to June 15th, they live in the "low mountains": each family has a second house in the hamlets within a radius of $3 \mathrm{~km}$ around Chef-lieu (between 1480 and $2080 \mathrm{~m}$ a.s.1.). In June, they go to the "high mountains" up to $9 \mathrm{~km}$ away from Chef-lieu (between 1880 and $2050 \mathrm{~m}$ a.s.l.). In October, they return to the houses in the lower mountains before spending the winter in Chef-Lieu. While during the spring, when the barns in Chef-Lieu are empty after the winter and the surrounding fields are still snowy because they are at the bottom of the valley, the families move to "low mountain" houses. There, they finish the provisions of the previous year which were already put aside in the autumn. Moreover, the "low mountain" slope favours the snowmelt, enabling the animals to return to the pastures earlier than at the bottom of the valley. From June on, the large amount of work to be done in the high mountains - herding, harvesting hay, making dairy products - makes it necessary for the inhabitants to move again. This way of life imposes many displacements, perhaps the separation of families between two or three houses, as there are harvests to be made in the middle of summer around Chef-Lieu as well as in the low mountains.

\subsection{Hamlets and houses designed for agropastoral work}

Permanent villages or small mountain hamlets all have a very compact housing design in order to save space for farmland and to reduce daily trips to communal facilities such as fountains to collect water.

All the houses have an impressive volume: far from being a sign of wealth or a large family, the dimensions are explained by the harsh climate: the longer the winter, the more fodder must be stored to feed the livestock in the stables. Thus, the harvests made in the low mountains were stored in the highest floors of these houses and consumed in the inter-season.

In Cervières, as elsewhere in the region and as in many mountain areas, rural architecture has the same objectives: to house a family and its livestock, to preserve crops and food, to allow the work of each season to be carried out (including the care of livestock), and to enable the preparation of meals and dairy products. Far from being a simple dwelling, the house is also a work place and as such, a tool designed and organized to facilitate seasonal tasks. The climate 
- again - makes it necessary to bring together all the functions of the farm and the family home under one roof: a common stable (where one eats and sleeps with the livestock), the kitchen, a cellar and the barn constitute a unitary building. These buildings do not have any outbuildings as the large amount of snow in winter would make daily movements between the house and its outbuildings very difficult.

For this reason, the ground floor is insulated from the cold by masonry walls at least $50 \mathrm{~cm}$ thick, while on the upper floors the wood barn is always very well ventilated to allow the harvest to dry out and thus eliminate any risk of fermentation.

Moreover, the layout of the house is designed to facilitate daily circulation: every day, several round trips are necessary between the stable and the barn to feed and milk the cattle. Then, for the manufacture of dairy products, there was movement between the stable, the kitchen fireplace, and the cellar, where finished products were stored. As both men and women often circulated within the house carrying heavy loads, the frequented areas were designed to facilitate these movements.

\subsection{Wood, a central element of daily life at Cervières}

In Cervières, as elsewhere in the region, wood is present across the landscape, it is employed in construction, and used for furniture and tools, and this lasted until the first half of the 20th century. It is, along with stone, the essential component of any civil construction effort. Wood is also the only material used for furniture: tables, chairs, dressers, modest grain chests, richly decorated linen chests, lovingly carved wedding boxes, pencil boxes and schoolbags - wood is present in all domestic activities (Mallé, 1999; Putelat, 2012).

When leaving the house, it is still wood that has enabled the creation of collective facilities such as fountain basins, washing places or mills. Garden fences are made of wood, as are engineered structures such as bridges and parts of the irrigation canals.

The forest itself fulfils multiple functions: the larch trees offer their open, green spaces for grazing and all the forests on the mountain slopes protect the crops and the houses below from avalanches and mudslides.

Wood is so much a part of everyday life in the region that it is used in certain names. At Cervières in 1601, for example, M. Jean Brac-Fustier delivered wood at Briançon castle. The name "Fustier" can be derived from the old French word "fust" which means wood block or timber. This man undoubtedly had a trade related to wood. In another example, the large number of persons named "Faure-Vincent" made it necessary to differentiate them by using nicknames evoking their activities or character. Thus, the house-museum studied in this paper is the property of the Faure-Vincent du Bois family, "bois" meaning "wood".

In this study, by combining historical, archaeological and dendrochronological approaches, we will determine the lifespan of Cervières houses, their different building phases, and start reconstructing the ancient appearance of the local forests. This will allow us to have a better understanding of the ancient mountain way of life, which has now disappeared.

\section{$\underline{\text { 2. Material and Methods }}$}

\subsection{Description of the studied houses}

The houses were selected on the basis of their dendrochronological potential and the ease of intervention (authorization of the owners, accessibility of the wood pieces). Six houses located in five hamlets between 1395 and $2061 \mathrm{~m}$ a.s.l. were studied (Fig. 2 and Tabl. 1). Five are still inhabited, one is abandoned. All of them were once farms with a stable on the lower level and a barn on the upper levels. One of the houses (0502704) is not located on the actual territory of 
Cervières, but $550 \mathrm{~m}$ west of the present boundary. However, we have chosen to include it in this study because it has similar architectural characteristics.

A historical study was carried out for one of these six farms, the Maison-Musée Faure-Vincent Dubois (0502701). For this purpose, a detailed description of the farm layout was carried out and 747 objects (or batches of objects) kept in the house were inventoried.

\subsection{Field sampling and dendrochronological analysis}

We sampled between 5 and 42 timbers per house, which represent 90 timbers in total. We used a Pressler increment borer (Haglöf, Sweden), an electric Rinntech drill, and sometimes, when timbers were removed from the structure (e.g. during restoration work), a section was cut with a chainsaw.

In the laboratory, wood species were determined (Schweingruber, 1990) and ring-widths were measured using the incremental measuring table LINTAB with $0.01 \mathrm{~mm}$ accuracy and TSAPWin software (Rinntech, 2014). Then, with DENDRON IV free software (Lambert, 2006), treering series were indexed using the Corridor, a polynomial indexation which takes into account the amplitudes of the inter-annual variations while preserving the average frequency variations. This indexation implements three polynomials instead of one, as is often the case in polynomial regressions: one polynomial for midpoints (1), one for points above the midpoint (2), and one for points below the midpoints (3). Then, centring (i.e. forcing the midpoint to zero) is done by taking into account the difference between the point calculated by polynomial 2 and polynomial 3 (and not by taking into account the midpoint). The result is a curve that fits into an almost perfect rectangle, very similar to the raw series (Durost, 2005; Lambert, 2006) (Fig. 3).

Once indexed, the curves were cross-dated using the Student test $(t)$. The originality of Student's $t$ employed in this work is the use of the average of two correlation coefficients $\left(\mathrm{r}_{\text {moy }}\right)$ : the first, $r_{1}$, standard, calculates the correlation between the values of the ring thicknesses, the second, $\mathrm{r}_{2}$, determines the correlation of the differences between two successive years (i.e. between the inter-annual slopes) (Lambert, 2006).

\section{$\underline{\text { 3. Results and discussion }}$}

\subsection{Wood identification and description}

Some of the timbers studied are Larch (Larix decidua Mill.) $(\mathrm{n}=29)$, but most of them are Scots pine t. (Pinus sylvestris $\mathrm{t}$.) $(\mathrm{n}=61)$.

If an attempt is made to identify the species of pine used, we might mention that Cervières mountain pines are too tortuous to set up long structural beams so they can be discarded. Moreover, the lower the altitude of the houses, the more pine beams they have: this coincides more with the Scots Pine area of distribution than that of mountain pine. Even if we will never have absolute proof, it therefore seems that Scots pine was primarily used in the houses of Cervières.

Larch timbers come from slightly older trees than the Scots pine t. timbers (142 and 124 years old in average, respectively) and the averages of timber circumferences are comparable (65 and $69 \mathrm{~cm}$, respectively) (Tabl.2). Since the mechanical properties of larch and Scots pine are very close (Barnett, Jeronimidis, 2003), these beams of similar age and circumference could therefore perform the same functions within constructions. 


\subsection{Dendrochronological dating}

\subsubsection{Larch samples}

Twenty-five of the 29 series of larch trees correlate and their average, 526 years long, covers the period from 1380-1905 $\left(t=9.92, r_{\text {moy }}=0.42\right)$ (Fig. 4), position replicated on 55 reference chronologies).

\subsubsection{Scots pine t. samples}

Twenty samples of the 61 Scots pine t. series correlate and their average length is 344 years. It was compared with our Scots pine reference frame (47 average chronologies from living trees) covering the period from 1332-1999, but no satisfactory correlation was obtained. We worked with other standardisations (raw data, logarithmic standardisation), other tests (seven years moving windows named "Except from Besançon", Lambert, Lavier, 1992), as well as deconstructing this average, but it did not provide reliable results.

Although promising results in Scots pine dating and provenancing when using Blue Intensity were obtained by Wilson et al. (2017) for Scotland and by Akhmetzyanov et al. (2020) on the Iberian Peninsula, it should be noted that Scots pine t. in the Southern Alps is a recalcitrant species from the tree ring thickness synchronisation point of view (Miramont et al., 2011; Shindo, 2016; Capano et al., 2019).

We therefore compared this Scots pine t. average to the local larch reference chronologies over the period extending from 1530-1873. The best correlation is obtained with the Buffère Larch building chronology (J.-L. Edouard, $t=5.15, r_{\text {moy }}=0.26$ ), located at $20 \mathrm{~km}$ linear distance northwest of Cervières (Fig. 5). A $t>4$ result is generally fully acceptable for larch correlations in this region, and, since the visual comparison of the curves is good, especially for midfrequency variations, we consider that this dating is correct. Moreover, in this Scots pine t. average, seven timbers of the same house are thus dated in 1730. This date can be linked to the inscription "1731" engraved on this house (Fig. 6): the dating inscription and the dendrochronological dating match, which reinforces the dating of the entire average.

To our knowledge, this is the first time in the Southern Alps that archaeological Scots pine $t$. series have been dendrochronologically dated.

As a synthesis, the square correlation matrix in figure 6 shows the level of correlations between all the Cervières timbers (Student $t$ ). These timbers have been grouped by site and construction phases. The darker the square, the better the correlation.

\subsection{History of the Maison-musée Faure-Vincent Dubois: textual and dendrochronological sources}

All the timbers in the barn of this structure date from the first half of the 18th century (with a large felling phase in 1730-1731). However, in textual sources, the earliest mention of this building dates from 1820, when Cervières land registry is carried out. Although it was only previously assumed that the house was built before 1820, dendrochronology now provides clear proof of this (Fig. 7).

In 1820, it was a single building belonging to a single owner. According to the land registry, the house was divided between two owners in 1866. The larch joist that marks the addition of the interior staircase between the small entrance hall and the barn is more recent (dendrochronological felling date between 1906 and 1919, confidence level $95 \%{ }^{1}$ ). This proves the hypothesis made by historians of the later staircase and entrance hall add-ons (Mallé, 1999, p. 222). The latter may have been constructed after the house was divided in two, so that both houses had one entrance.

\footnotetext{
${ }^{1}$ Based on an extensive analysis of 267 living larch trees from the Southern French Alps, L. Shindo (2016) determined, that larch sapwood rings number ranged between 14 and $50(32 \pm 18)$, with a 95\% confidence level. This means $95 \%$ of the larches have 14 to 50 sapwood rings.
} 
In the inventory of the 747 objects (tools and furniture) conserved in the house, 301 are made of wood of which 111 are related to woodworking. Some of these objects, such as furniture, could be the subject of a dendrochronological study based on photographs (like the big wooden grain cabinet in the cellar, see Fig. 7). The dating documents the history of the activities carried out with these objects and could perhaps be associated with one of the house's construction phases.

\subsection{Felling phases, tree circumference and species used over time}

When looking at the diagram of all dated timber (Fig. 8), it can be seen that there was almost continuous logging from the second half of the 16th century to the 20th century. The oldest timbers are dated from the end of the 16th century to the middle of the 17th century. Subsequently, no timbers felled in the second half of the 17th century were recorded. Does this reflect a bias in our sampling or a reality of construction? The second major felling phase is identified during the first half of the 18th century, when almost half of the dated timber in this valley was felled.

A third small felling phase took place at the end of the 18th century and the last one occurred in the second half of the 19th century.

The dated timbers were divided into three groups, according to their circumference (note that this is the circumference of the timbers and not that of the tree. However, on the whole, the studied timbers were not squared so that the circumferences used here must be close to those of the standing trees). The circumferences of the dated timber range from 46 to $114 \mathrm{~cm}$, and have been divided into three groups: group $a(46-68 \mathrm{~cm})$, group $b(69-91 \mathrm{~cm})$ and group $c(92-114$ $\mathrm{cm})$. In figure 8, they are symbolized by three circle sizes placed at the end of each horizontal bar.

During the first felling phase, there are only timbers of circumference $a$ and $b$ : perhaps there were no trees of large circumference available form the end of the 16th century until the middle of the 17th century. If they existed, we have no trace of these large trees today. Did they completely disappear before the first half of the 17th century? Or were they used in ways that left no trace (for exportation or as firewood)? Recourse to written archives can provide answers, for example, we could search in "the wood accounts that the inhabitants of Cervières provided to the castle of Briançon during the year 1601" (Richard 1601). It was the "wood collector", Mr Esprit Richard, who kept this register, noting down the names of the suppliers (the names of 120 Cervières inhabitants are thus known), the quantities of wood delivered, and the amount of money paid. The delivered wood may have been used for the restoration and enlargement of the Briançon castle as well as for heating. Statistical interpretation of these data would make it possible to specify the exploitation of Cervières forests at the beginning of the 17th century, associated of course with new dendrochronological samples.

In the second felling phase, there are timbers of all circumferences. The oldest of them, which are also the largest, started to grow during the first phase, which also means that during the first felling phase, the forests also regenerated themselves. Although these large trees had time to grow well before being felled in their turn, it is not possible to say whether they had been deliberately preserved for future constructions. Finally, in the third and fourth felling phases, timbers of all circumferences were used. Therefore, from the first half of the 18th century (second felling phase) to the 20th century, trees of all sizes were available in Cervières forests . The oldest felling phase is only represented by larch trees. The two houses, which include the old larch wood specimens, are also those from the highest altitudes (2061 and $1904 \mathrm{~m}$ a.s.l., respectively). The question is thus raised, if the old habitat specimens were installed at high altitude or did the houses located at lower altitudes undergo more restorations, making the oldest timbers disappear? The latter seems all the more likely as fires were probably more numerous in Chef-lieu than in the high-altitude hamlets, which were less frequently occupied. 
The use of Scots pine t. in building is only attested from the first half of the 18th century and thereafter it is used just as much as larch. We saw earlier that the mechanical properties of larch and Scots pine are similar. In this case, why was Scots pine t. not used earlier before the 18th century? We do not yet have an answer to this question, but we can imagine that larch trees were more easily accessible and that people turned to this species rather than to Scots pine $t$. Moreover, it can be hypothesised that during the first half of the 18th century, larch trees were deliberately spared in order to maintain the grass in the pastures. In fact, unlike other conifers, grass grows without difficulty at the foot of the larch trees and its low branches are high enough to allow people and herds to pass through (Duhamel du Monceau, 1755; Fourchy, 1952).

\section{Conclusion}

In view of all the wooden buildings in the Cervières Valley, the samples taken from the six farms studied here may seem insufficient to understand the relationship between the inhabitants and the forest. However, this is an initial working base which will be gradually completed and the first results are promising.

For the moment, the 90 sampled timbers (45 dated) indicate that only larch and Scots pine t. were used in the building structures from the end of the 16th century to the second half of the 19th century. This is the first time that archaeological Scots pine t. wood has been dendrochronologically dated in this region. It seems that trees of all circumferences grew in the Cervières forests between the first half of the 18th century and the 20th century, whereas from the end of the 16th century to the middle of the 17th century, only larch trees of small and medium circumference were available. These hypotheses will, of course, have to be confirmed in the coming years, particularly by making careful use of archive texts.

The oldest dendrochronological dates are from the 16th century, while, according to the historical texts, Cervières exists since the 12th century. In order to access the oldest building elements (if they are preserved), further dendrochronological investigations in houses and hamlets not yet studied should be carried out. In addition, we plan to carry out analyses on soilanthracological pits at different altitudinal gradients in the valley to identify the trees that once grew there.

\section{Acknowledgements}

We would like to thanks the owners of buildings in the Cervières Valley who allowed us to take samples from their wooden structures and who helped us on the field. Special thanks are extended to the 'Association pour l'étude et la sauvegarde de la vallée de Cervière' and Bernadette Brunet for her support.

We would also like to thank Brigitte Talon (IMBE Aix-en-Provence, CNRS, France) and Gilles Astier (Restauration des Territoires de Montagne, Hautes-Alpes, France) who provided us with explanations on the ecology of the Scots pine in Cervières.

Finally, we would like to thank Eileen Kücükkaraca (ROOTS, Kiel University) for the editing of English and the two anonymous reviewers for their pertinent advice and encouragement.

\section{Funding}

Deutsche Forschungsgemeinschaft (DFG, German Research Foundation) under Germany's Excellence Strategy - EXC 2150 ROOTS - 390870439. 


\section{$\underline{\text { 7-References }}$}

Akhmetzyanov L., Sánchez-Salguerob R., García-González I., Buras A., Dominguez-Delmás M., Mohrena F., den Ouden J., Sass-Klaassena U., 2020. Towards a new approach for dendroprovenancing pines in the Mediterranean Iberian Peninsula, Dendrochronologia, 60.

Alvarez S. G., Juaristi C. M., Gutierrez J S., Garcia-Amorena I., 2009. Taxonomic differences between Pinus sylvestris and $\mathrm{P}$. uncinata revealed in the stomata and cuticle characters for use in the study of fossil materia, Reviw of Palaeobotany and Palynology, 155, 61-68.

Barnett J.R., Jeronimidis G., 2003. Wood quality and its biological basis. Blackwell Publishing Ltd., Oxford, 226 p.

Capano M., Miramont C., Shindo L., Guibal F, Marschal C., Kromer B., Tuna T., Bard E., 2020. Onset of the Younger Dryas recorded with $14 \mathrm{C}$ at annual resolution in French subfossil trees, Radiocabon, 62, 4, 901-18 DOI: https://doi.org/10.1017/RDC.2019.116

Duhamel du Monceau H.-L., 1755. Traité des arbres et arbustes qui se cultivent en France en pleine terre, Tome 1er, H.-L. Guérin et L.-F. Delatour éditeurs, Paris, 369 p.

Durost S., 2005, Dendrochronologie et dendroclimatologie du $2^{\mathrm{e}}$ âge du Fer et de l'époque Romaine dans le Nord et l'Est de la France. Datation, système de références et modélisation. Thesis, Université de Franche-Comté.

Fourchy P., 1952, Ecologie du mélèze particulièrement dans les Alpes françaises. Etudes sur 1'Ecologie et la sylviculture du Mélèze (Larix europea D. C.), Extrait des Annales de 1'Ecole Nationale des Eaux et Forêts et de la Station de Recherches et Expériences, 13, 1, 137pp.

Lambert, G.-N., 2006. Dendrochronologie, histoire et archéologie, modélisation du temps. Le logiciel Dendron II et le projet Historik Oaks, V1 et V2, accreditation to supervise research, Besançon, 152 pp. and 206 pp.

Lambert, G.-N., 2011. Dendrochronology, archaeology and science, in: Fraiture P. (Eds.), Tree Rings, Art, Archaeology, Proceedings of the conference, Brussels, Royal lnstitute for Cultural Heritage, 10-12 February 2010. Scientia Artis 7, Brussels, pp. 19-30.

Lambert G.-N., Lavier C., 1992. L'étalon de datation dendrochronologique Bourgogne 29, Les veines du temps. Lecture du bois en Bourgogne, pp. 123-56.

Mallé M.-P., 1999. L'habitat du nord des Hautes-Alpes. Patrimoine architectural et mobilier, Association pour le patrimoine de Provence et Société d'étude des Hautes-Alpes, 440 pp.

Miramont C., Sivan O., Guibal F., Kromer B., Talamo S., Kaiser K. F., 2011. L'étalonnage du temps du radiocarbon par les cernes d'arbres. L'apport des séries dendrochronologiques du gisement de boi subfossiles du torrent des Barbiers (Alpes françaises du sud), Quaternaire, 22, $3,261-71$.

Putelat G., 2012. Meubles et objets anciens du Queyras et des vallées voisines : La passion Chevallier. Editions du Queyras, St-Veran, 240 pp. 
Richard E., 1601. "Compte-rôle du bois que les particuliers de la commune de Servières ont fourni au château de Briançon tant par les mandats de monsieur le secrétaire du Briançon que devant les dits mandats [word ?] l'année 1601". Escartons achives, accounting, accounting vouchers, E715, years 1601 to 1607, unpaginated booklet of 21 sheets, views 79 to 89 of the scan. Departmental archives of the Hautes-Alpes, France.

Archive can be viewed on this webpage: https://archives.hautesalpes.fr/ark:/23599/vta547ecfa080855/daogrp/0\#id:920922448? gallery=true \&brightness=100 . $00 \&$ contrast $=100.00 \&$ center $=1436.000,-2260.000 \&$ zoom $=5 \&$ rotation $=0.000$

RINNTECH, 2014. LINTAB. Precision ring by ring. http://www.rinntech.com/Products/Lintab.htm.

Schweingruber, F. H., 1990. Anatomie europäischer Hölzer: ein Atlas zur Bestimmung europäischer Baum-, Strauch-, und Zwergstrauchhölzer - Anatomy of European woods: an altas for the identification of European trees, shrubs, and dwarf shrubs, Bern, Verlag P. Haupt, 800 pp.

Shindo, L., 2016. Bois de construction et ressources forestières dans les Alpes du sud au IIe millénaire. Dendrochrono-écologie et archéologie. Thesis. Aix-Marseille University, France (on line: https://hal-sde.archives-ouvertes.fr/tel-01325760/).

Wilson R., Wilson D., Rydval M., Crone A., Büntgen U., Clark S., Ehmer J., Forbes E., Fuentes M. Gunnarson B. E., Linderholm H. W., Nicolussi K., Wood C., Mills C., 2017. Facilitating tree-ring dating of historic conifer timbers using Blue Intensity, Journal of Archaeological Science, 78, 99-111. http://dx.doi.org/10.1016/j.jas.2016.11.011 


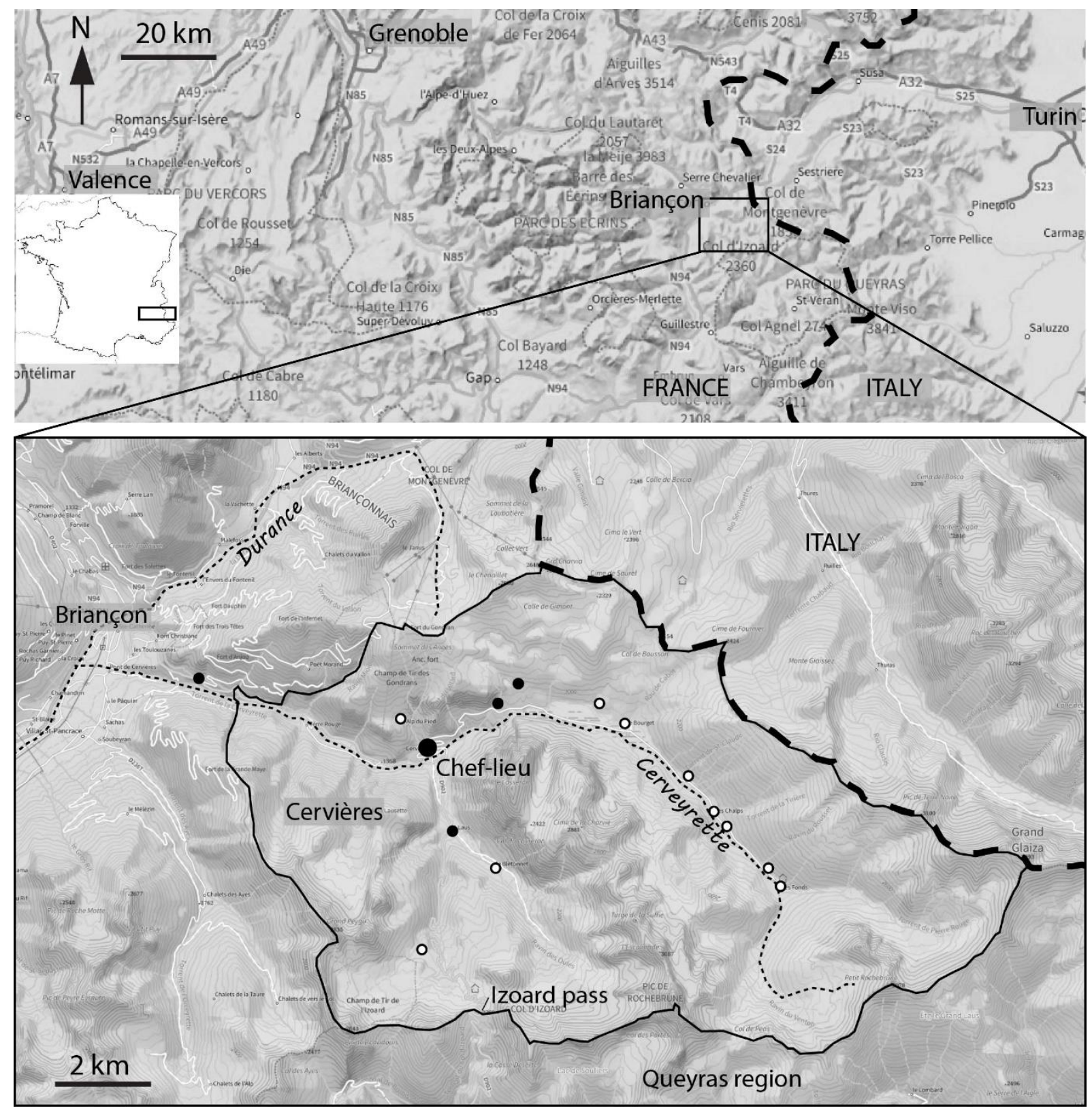

Fig. 1: Location of the Cervières commune in the Southern French Alps. On the lower map, the black dots correspond to the hamlets in which houses have been studied by dendrochronology, while no houses have been studied in the hamlets marked by white dots (map: Geoportail.fr). 


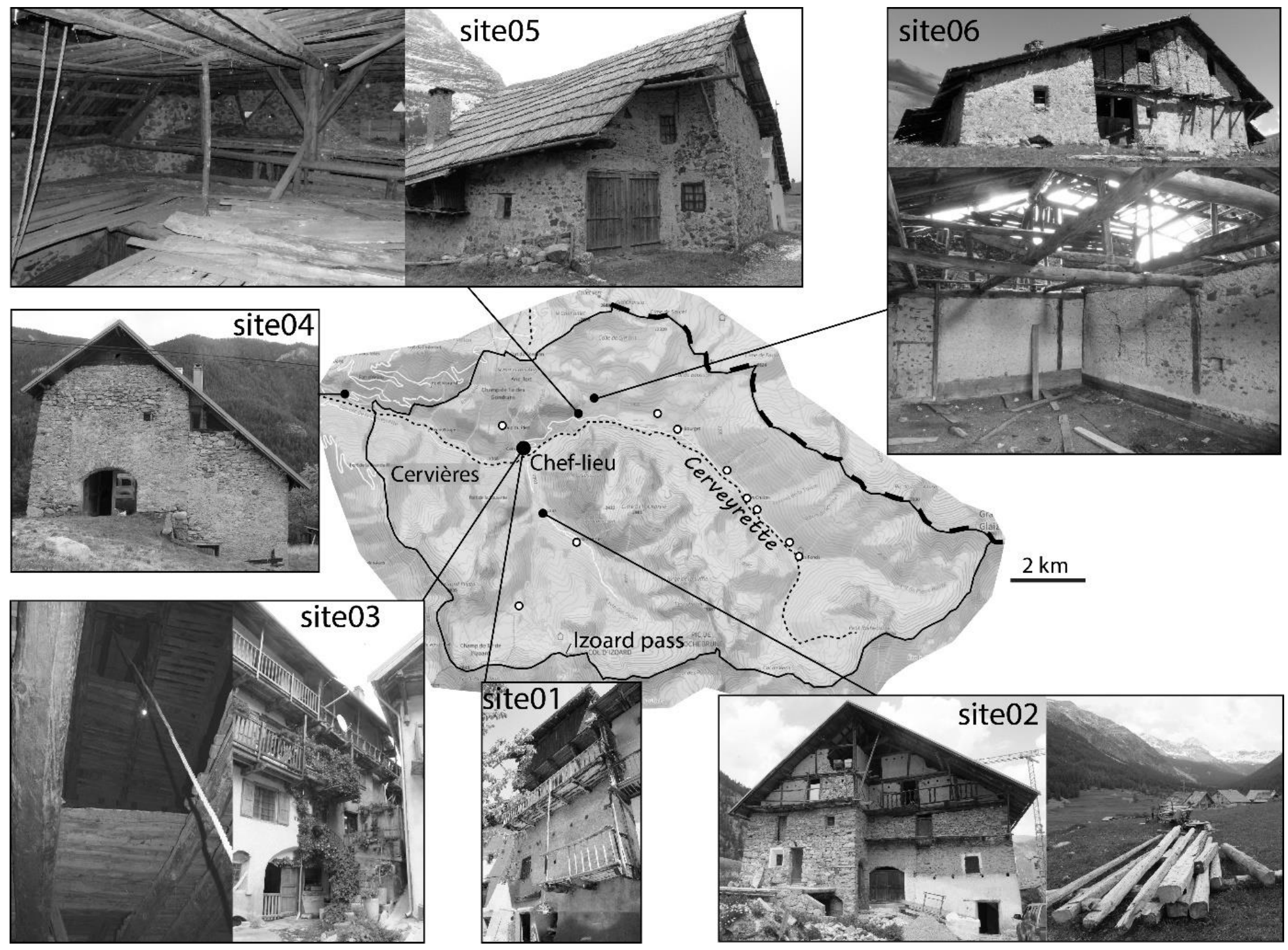

Fig. 2: The six studied houses in Cervières. 


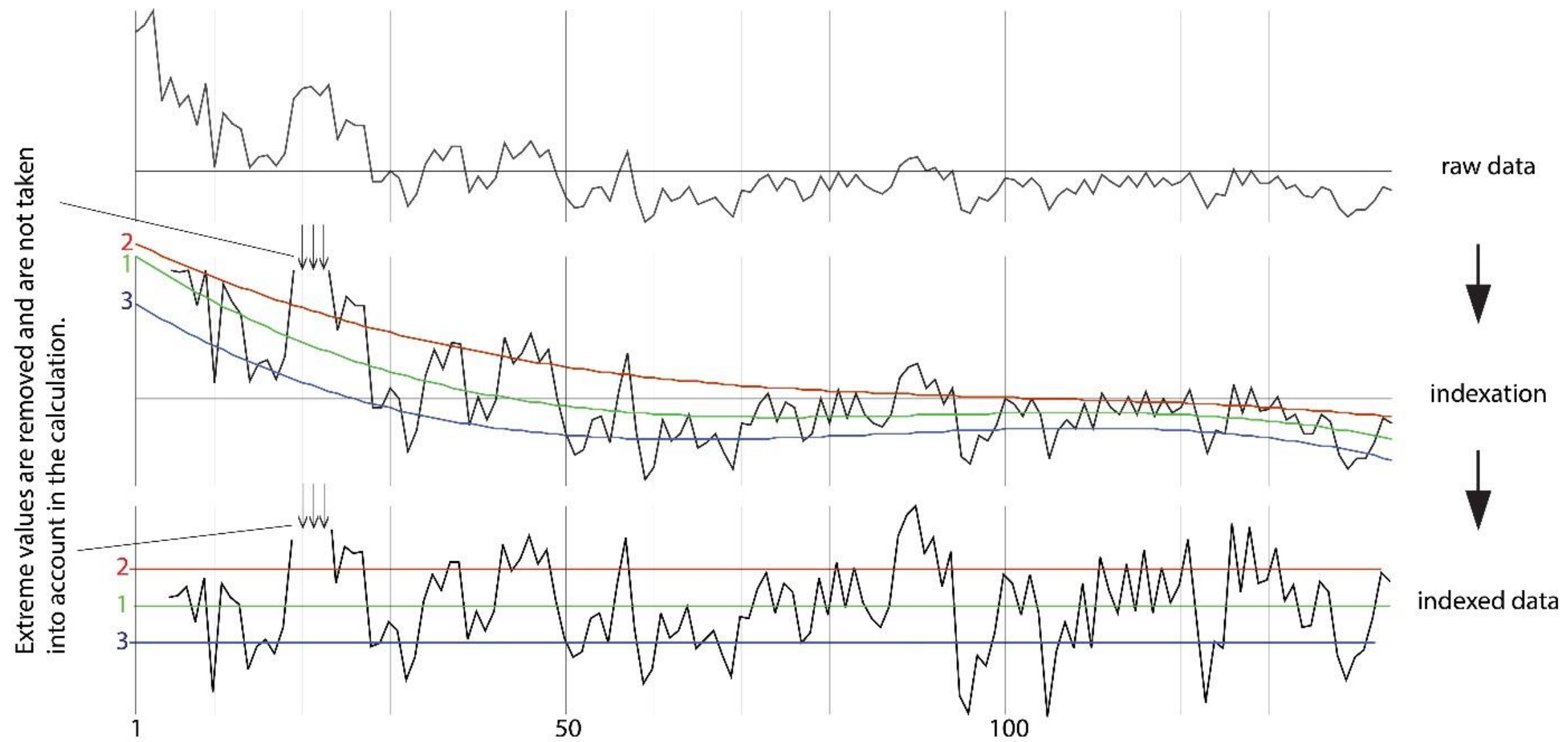

Fig. 3: Corridor indexation principle. In green (1) the midpoint polynomial, in red (2) the polynomial above the midpoints, in blue (3) the polynomial below the midpoints (from Lambert, 2011). 


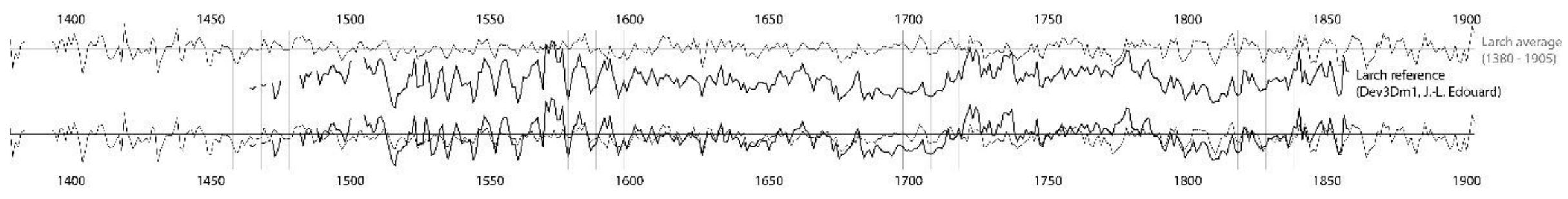

Fig. 4: Synchronisation of the Cervières larch average chronology with the larch Dev3Dm1 building chronology (J.-L. Edouard), Corridor standardisation. In the lower part of the graph, the two curves are shown superimposed to facilitate the reading of their comm on variations.

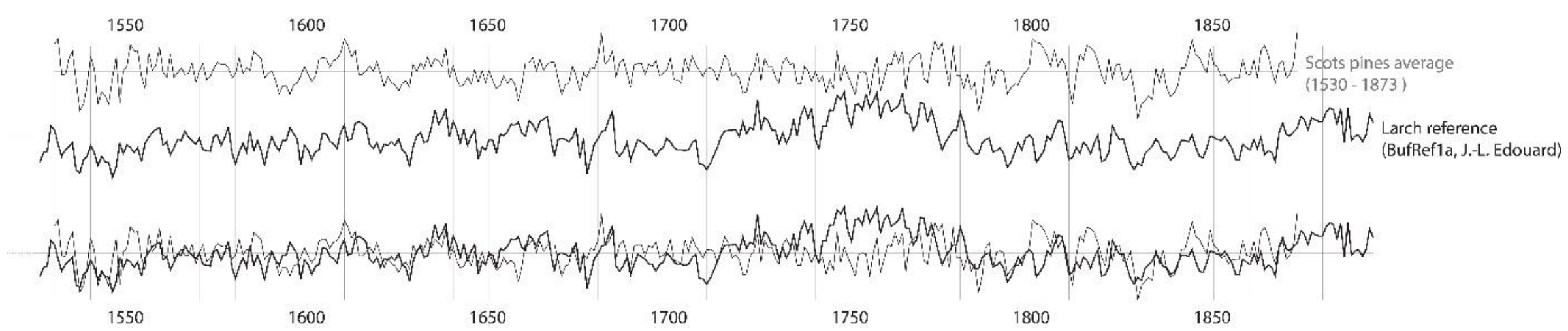

Fig. 5: Synchronisation of the Cervières Scots pine t. average chronology with the larch "Buffère" building chronology (J.-L. Edouard), Corridor standardisation. In the lower part of the graph, the two curves are shown superimposed to facilitate the reading of their common variations. 


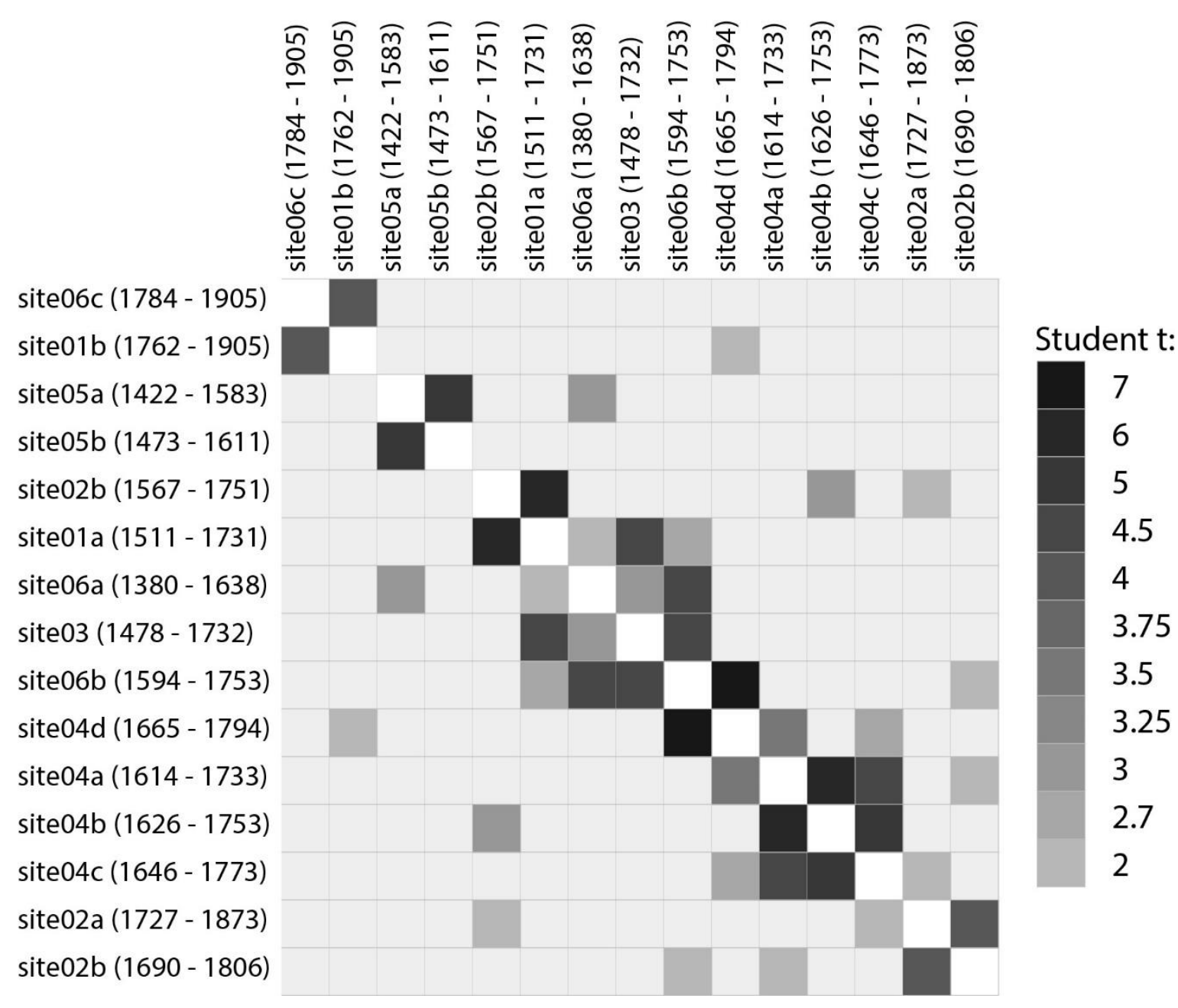

Fig. 6: Square matrix of the $t$-value for the 15 building phase chronologies (identified by small letters, from "a" to "c"). Matrix automatically drawn using the DENDRON-IV software (Lambert, 2006). 

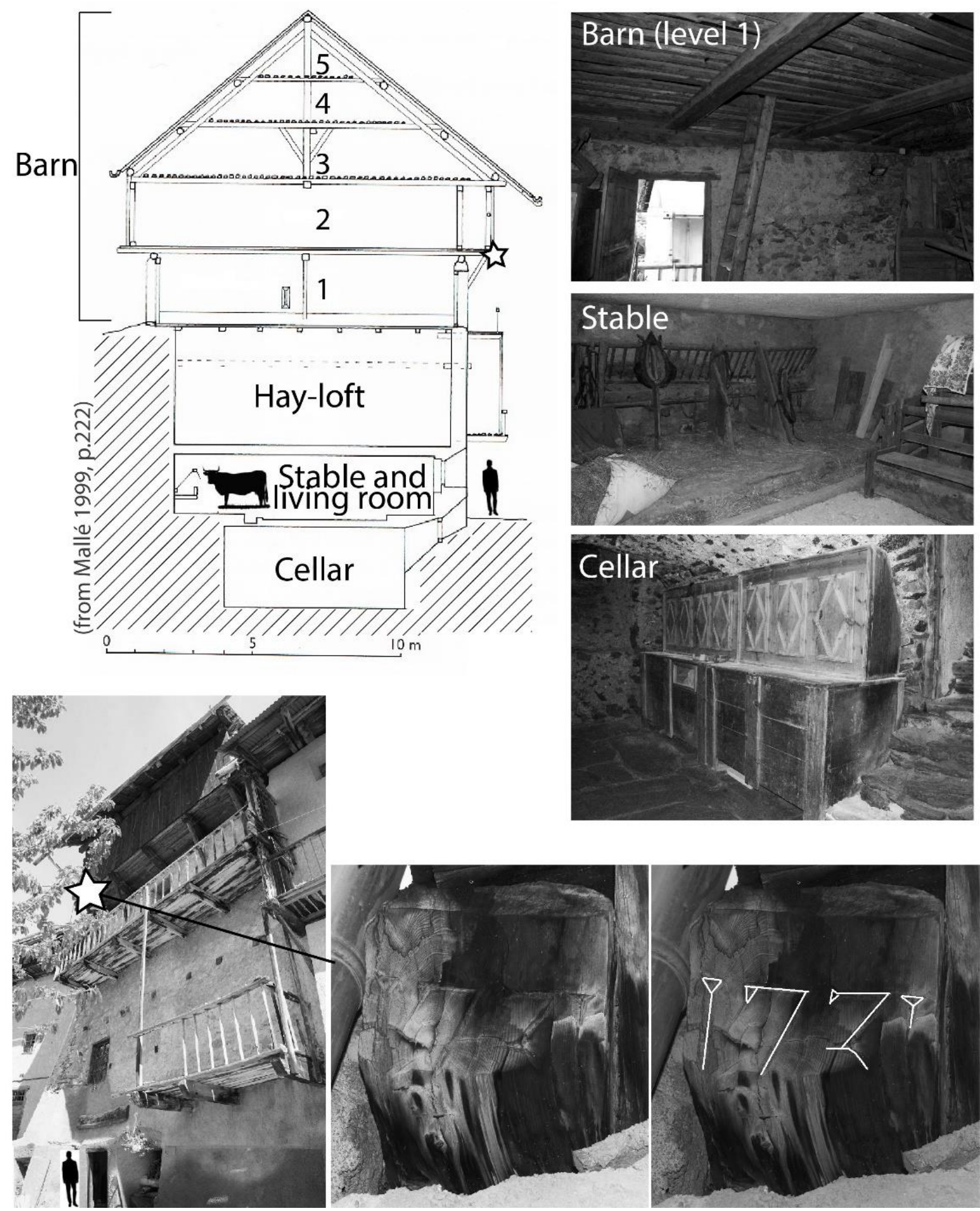

Fig. 7: The Faure-Vincent Dubois house-museum (0502701). Above, vertical section of the house (from Mallé, 1999) and photographs of the interior. Below, the south façade of the house and at the location of the star, the end of a purlin timber engraved with the date " 1731 ". 


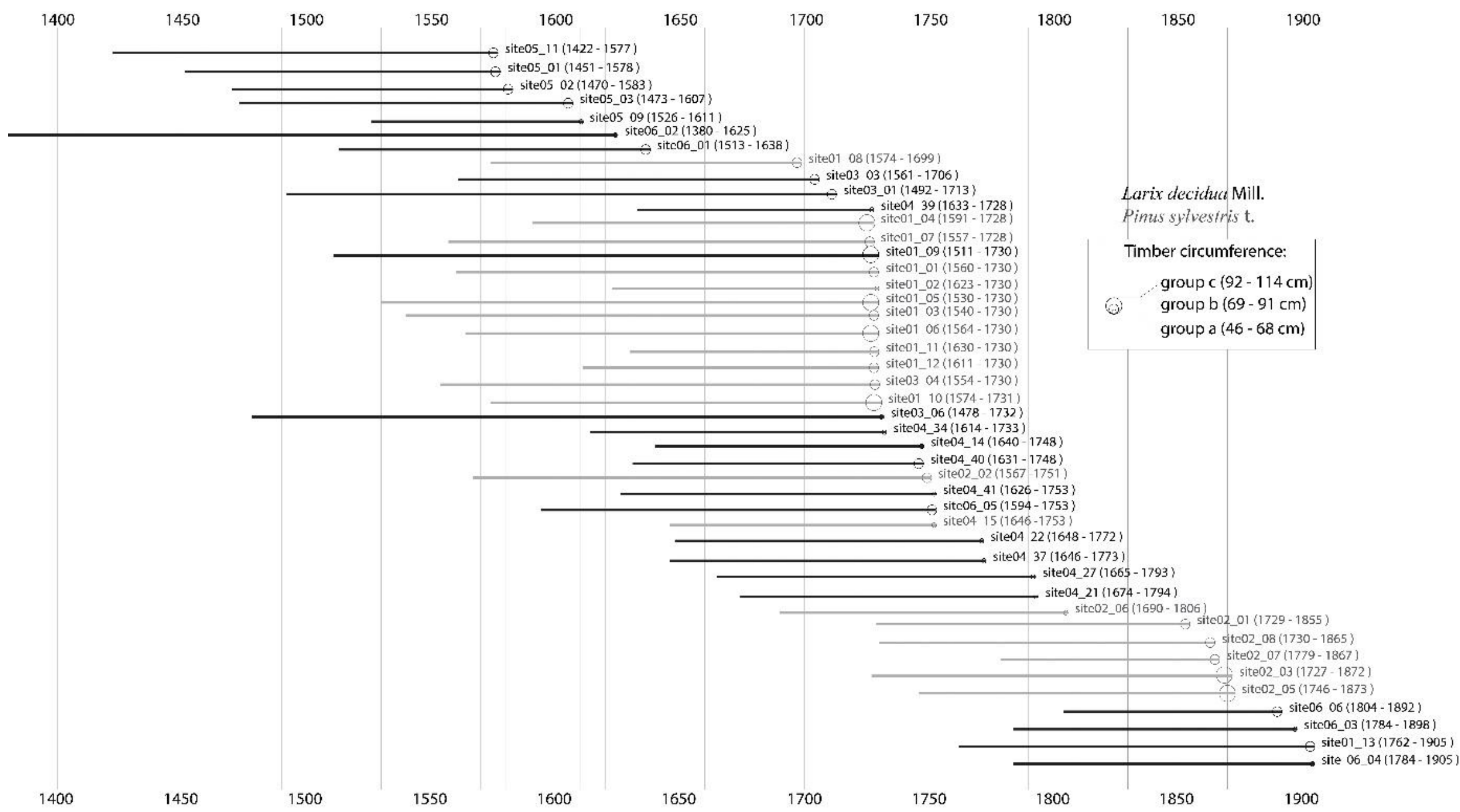

Fig. 8: Diagram of the 45 dated series, presented as horizontal bars. Larch in black, Scots pine in grey. The timbers' circumferences (three classes) are symbolised by three circle sizes at the ends of the bars. 


\begin{tabular}{|c|c|c|c|c|c|c|c|}
\hline $\begin{array}{l}\text { Dendro } \\
\text { code }\end{array}$ & Hamlet & Longitude (WGS84) & $\begin{array}{l}\text { Latitude } \\
\text { (WGS84) }\end{array}$ & $\begin{array}{c}\text { Altitude } \\
\text { (meters } \\
\text { above sea } \\
\text { level) }\end{array}$ & $\begin{array}{l}\text { Number of } \\
\text { wood pieces } \\
\text { analysed }\end{array}$ & Larch (dates) & $\begin{array}{l}\text { Scots pine t. } \\
\quad \text { (dates) }\end{array}$ \\
\hline site01 & Chef-lieu & 6.721224 & 44.869641 & 1620 & 13 & x2(1511-1905) & x11 (1574-1731) \\
\hline site02 & Le Laus & 6.726698 & 44.855603 & 1750 & 13 & x1 (undated) & $\mathrm{x} 12(1567-1873)$ \\
\hline site03 & Chef-lieu & 6.721703 & 44.869689 & 1620 & 5 & x3 (1478-1732) & x2 (1554-1730) \\
\hline site04 & Maison crénelée & 6.662365 & 44.882759 & 1395 & 42 & x10(1614-1794) & x32 (1646-1753) \\
\hline site05 & La Chau & 6.750907 & 44.880128 & 1904 & 10 & $\mathrm{x} 7(1422-1611)$ & x3 (undated) \\
\hline site06 & Les Fraches & 6.755406 & 44.885496 & 2061 & 6 & x6 (1380-1905) & 1 \\
\hline
\end{tabular}

Table. 1: Description of the six studied sites.

\begin{tabular}{|c|c|c|c|}
\hline & $\begin{array}{c}\text { Number of studied } \\
\text { timbers }\end{array}$ & $\begin{array}{c}\text { Average number } \\
\text { of rings }\end{array}$ & $\begin{array}{c}\text { Average } \\
\text { circumference }(\mathrm{cm})\end{array}$ \\
\hline Larix decidua Mill. & 29 & $142(\sigma=47)$ & $65(\sigma=18)$ \\
\hline Pinus sylvestris t. & 61 & $124(\sigma=40)$ & $69(\sigma=22)$ \\
\hline
\end{tabular}

Table. 2: Characteristics of the 90 samples of larch and Scots pine t. 